\title{
25 Research Soure \\ Affinibrenneria salicis gen. nov. sp. nov. isolated from Salix matsudana bark canker
}

\section{Dan-ran Bian}

Research Institute of Forest Environment Ecology and Protection

Han Xue

Research Institute of Forest Environment Ecology and Protection

Guang-ming Wang

Forest protection of Erdos

Chun-gen Piao

Research Institute of Forest of Environment Ecology and Protection

Yong Li ( $\boldsymbol{D}$ lylx78@hotmail.com)

Research Institute of Forest Environment, Ecology and Prottection https://orcid.org/0000-0002-4406-1329

\section{Research Article}

Keywords: phylogenomics, average nucleotide identity, multilocus sequence analysis

Posted Date: March 18th, 2021

DOl: https://doi.org/10.21203/rs.3.rs-319214/v1

License: (c) (i) This work is licensed under a Creative Commons Attribution 4.0 International License. Read Full License 


\section{Abstract}

L3-3HA ${ }^{\top}$, a Gram-negative-staining, facultatively anaerobic, motile bacterial strain, was isolated from the symptomatic bark of Salix matsudana canker in China. 16S rRNA gene analysis revealed that the novel strain shares the highest sequence similarity with Brenneria goodwinii $\mathrm{FRB} 141^{\top}(95.5 \%)$. In phylogenetic trees based on four housekeeping genes $(g y r \mathrm{~B}, r p o \mathrm{~B}$, atpD and infB) and the 16S rRNA gene sequence, the novel strain formed a separate branch from the five genera of the family Pectobacteriaceae (Lonsdalea, Brenneria, Dickeya, Pectobacterium and Sodalis), suggesting that the novel strain should belong to a novel species of a novel genus within the family Pectobacteriaceae. The result was also supported by phylogenomics, amino acid identity and average nucleotide identity. The major fatty acids were $\mathrm{C}_{14: 0}, \mathrm{C}_{16: 0}$, $\mathrm{C}_{17: 0}$ cyclo, and $\mathrm{C}_{19: 0}$ cyclo $[8 \mathrm{C}$. Genome analysis showed that the novel strain has a large genome $(5.89 \mathrm{Mb})$ with 5,052 coding genes, including 181 virulence genes by searching the pathogen-host interactions database (PHI-base), indicating that the novel strain is a potential pathogen of plants and animals. Based on phenotypic and genotypic characteristics, the $\mathrm{L} 3-3 \mathrm{HA} \mathrm{A}^{\top}$ strain represents a novel species of a novel genus in the Pectobacteriaceae family, for which the name Affinibrenneria salicis gen nov. sp. nov. is proposed. The strain type is $\mathrm{L}^{3}-3 \mathrm{HA} \mathrm{A}^{\top}\left(=\right.$ CFCC $\left.15588^{\top}=\mathrm{LMG} 31209^{\top}\right)$.

\section{Introduction}

Adeolu et al. proposed a novel order, Enterobacterales ord. nov., based on phylogenomics and taxonomy that divided the original family of Enterobacteriaceae into seven families, Enterobacteriaceae, Erwiniaceae, Pectobacteriaceae, Yersiniaceae, Hafniaceae, Morganellaceae, and Budviciaceae (Adeolu et al. 2016). The family Pectobacteriaceae contains five genera, Pectobacterium (Waldee 1945), Brenneria (Hauben et al. 1998), Dickeya (Samson et al. 2005), Lonsdalea (Brady et al. 2012), and Sodalis (Dale et al. 1999). At the time of writing this manuscript, Pectobacteriaceae comprises five genera, 36 species, and 15 subspecies with validly published names (https://lpsn.dsmz.de/family/pectobacteriaceae) (Parte 2018).

A novel strain, $\mathrm{L}^{3}-3 \mathrm{HA} \mathrm{A}^{\top}$, was isolated from the symptomatic bark of Salix matsudana canker. The novel strain belongs to the family Pectobacteriaceae based on 16S rRNA gene sequence analysis. In the family Pectobacteriaceae, many species are associated with plant disease, such as Pectobacterium carotovorum, Brenneria salicis, and Lonsdalea populi. To explore the possible function of the novel strain, genome comparison among the novel and five reference strains was performed, and virulence genes and carbohydrate-active enzymes of the novel strain were predicted by searching the carbohydrate-active enzyme database (CAZy) and pathogen-host interactions database (PHI-base). To confirm the taxonomy status of the novel strain, polyphasic approaches, including 16S rRNA gene sequence analysis, multilocus sequence analysis (MLSA), phylogenomics, average nucleotide identity (ANI), amino acid identity (AAI), digital DNA-DNA hybridization (dDDH) and phenotypic characterization, were performed in the present study.

\section{Materials And Methods}

\section{Isolation and cultivation of the novel strain}


The novel strain was isolated from the bark samples of Salix matsudana canker as described by Li et al.

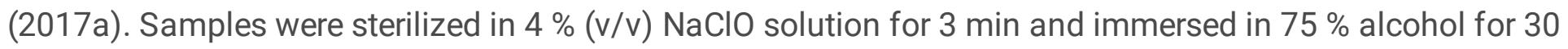
s. After rinsing three times with sterile water, the sterilized bark samples were cut into $2 \times 2-\mathrm{mm}$ pieces and soaked in sterile water for $30 \mathrm{~min}$. The solutions were diluted with sterile water to a series of $1: 10^{-1}$ to $10^{-4}$ and spread on tryptic soy agar plates (TSA; Difco). Single colonies were obtained after incubating at $30{ }^{\circ} \mathrm{C}$ for $48 \mathrm{~h}$. The strain was deposited at the Laboratorium voor Microbiologie, Universiteit Gent (LMG 31209 ${ }^{\top}$ ) and China Forestry Culture Collection Center (CFCC $15588^{\top}$ ).

\section{Sequencing of the 16S rRNA gene and phylogenetic analysis}

16S rRNA gene sequences were determined using bacterial universal primers $8 \mathrm{~F} / 1525 \mathrm{R}(5 \mathrm{c}$ AGAGTTTGATCCTGGCTCAG-3 $\dot{c}$ and 5ל́-AAGGAGGTGATCCAGCC-3Ç) as described by Lane (1991) and Baker et al. (2003). The EzBioCloud identify service (Yoon et al. 2017) was used to analyze 16S rRNA gene sequence similarities with validly published species.

Phylogenetic analysis of the 16S rRNA gene was performed according to Li et al. (2016). 35 almost complete (1344 bp) 16S rRNA gene sequences were aligned and overhangs trimmed using CLUSTAL W in MEGA 7.0 software (Kumar et al. 2016). The trees were reconstructed using the neighbor-joining and maximum likelihood methods and were evaluated with 1000 replicates.

MLSA based on four housekeeping gene partial sequences ( $g y r \mathrm{~B}, 745 \mathrm{bp} ;$ rpoB, $637 \mathrm{bp} ;$ atpD, $642 \mathrm{bp}$; and infB, $615 \mathrm{bp}$ ) was performed on the novel strain and reference type strains (Brady et al. 2013). The reference strain sequences of genera Lonsdalea, Brenneria, Dickeya, Pectobacterium, Sodalis, Izhakiella, Pantoea and Mixta were downloaded from GenBank (Table S1), and the sequences of the novel strain were retrieved from its genome sequence data. Phylogenetic trees based on the maximum likelihood and neighbor-joining method were reconstructed by Mega 7.0. The bootstrap method with 1,000 replicates was performed.

\section{Whole-genome sequencing}

Genome sequencing of the novel strain was performed using Illumina Miseq sequencing strategies as described by Li et al. (2016). The library was constructed with 300- to 500-bp DNA fragmentation using the TruSeq $^{\text {t" }}$ Sample Prep Kit. Sequence assembly was performed using SOAPdenovo v2.04. Coding sequences were predicted using Glimmer 3.02 software. Functional annotation of the protein sequences was performed against the nonredundant GenBank database using BLASTp.

An almost full-length 16S rRNA gene sequence obtained by conventional Sanger sequencing was compared with the sequence extracted from whole-genome assembly. Two sequences $(1,409 \mathrm{bp}$ and $276 \mathrm{bp})$ from the genome sequence shared 100 and $99.26 \%$ sequence similarity with the 16S rRNA gene sequence obtained by conventional Sanger sequencing. However, the 276-bp sequence may not be a 16S rRNA gene sequence, as confirmed by two methods. First, the DNA used for genome sequencing was PCR (polymerase chain reaction) amplified and sequenced by conventional Sanger sequencing, and no doublet and impure peaks were found. Second, the K-mer and GC-depth figures were regular and normal in the genome sequence analysis (Fig. S3 and S4). 
As recommended by Chun et al. (2018), phylogenomics, DNA-DNA hybridization and ANIb analysis were used for the taxonomy of the novel strain. Phylogenomics was performed on the novel and its closely related reference species. The genomic coding sequences were clustered using CD-HIT v4.6.1 (c 0.5 -n 3 -p 1 -T 4 -g 1 -d 0 -s 0.7 -aL 0.7 -aS 0.7) (Fu et al. 2012). Six hundred eighteen single-copy genes were selected using Perl scripts and aligned using Muscle 3.8.31 (Edgar 2004). A phylogenetic ML tree was constructed based on the resulting multiple alignments using PhyML V3.3 (Guindon et al. 2010) (parameters: phyml -i temp. phy -d aa -b -4 -m LG -a e -c 4 -t e >ml.log). The level of support for internal branches was assessed using the Bayesian test in PhyML.

Average nucleotide identity (ANI) is a similarity measure between two genome sequences that can be used to replace DNA-DNA hybridization (Richter et al. 2009; Goris et al. 2007). The OrthoANI values between the L3-3HA ${ }^{\top}$ strain and five reference type strains of the five genera of the family Pectobacteriaceae and other reference strains were calculated using the ANI calculator tool of the EzBioCloud website (https://www.ezbiocloud.net/tools/ani).

dDDH was conducted using the genome-to-genome distance calculator (GGDC) and the free web service at http://ggdc.dsmz.de/ based on genome sequences (Meier-Kolthoff et al. 2013). Amino acid identity (AAI) analysis among the novel and reference strains of genera Lonsdalea, Brenneria, Dickeya, Pectobacterium, and Sodalis was performed as described by Konstantinidis and Tiedje (2005).

Genome comparison among the novel strain and $D$. chrysanthemi $\mathrm{NCPPB}_{402}{ }^{\top}$, S. praecaptivus $\mathrm{HS}^{\top}, P$. carotovorum LMG $2404^{\top}$, B. salicis DSM $30166^{\top}$ and L. quercina ATCC $29281^{\top}$ was performed. The genomic coding sequences were clustered using CD-HIT v4.6.1 (Fu et al. 2012).

To understand the potential function of the novel strain, virulence genes and carbohydrate-active enzymes were predicted by searching the Carbohydrate-Active enZYmes Database (CAZy) (Lombard et al. 2014) and Pathogen-Host Interactions database (PHI-base) (Urban et al. 2020) using DIAMOND (Buchfink et al. 2015) based on the genome amino acid sequence of the novel strain (evalue $\leq 1 \mathrm{e}-5$, identity $\geq 50 \%$, coverage $\geq 40$ $\%)$, respectively. PHI-base is a web-accessible database that catalogs experimentally verified pathogenicity, virulence and effector genes from fungal, oomycete and bacterial pathogens (Urban et al. 2020). CAZy is a specialist database dedicated to the display and analysis of genomic, structural and biochemical information on carbohydrate-active enzymes (CAZymes) (Lombard et al. 2014).

\section{Morphological, physiological and biochemical analyses}

Colony morphology, motility and growth conditions (temperature and $\mathrm{NaCl}$ tolerance) experiments were performed according to the description of Li et al. (2017b). Cell morphology was examined by transmission electron microscopy with cells grown on TSA for $24 \mathrm{~h}$ at $30^{\circ} \mathrm{C}$. The motility of the novel isolate was examined by observing cells developed on wet mounts using a phase-contrast microscope (TMS-F; Nikon). The novel strain was inoculated in tryptic soy broth (TSB; Difco) and incubated at different temperatures (4, $10,30,37$ and $50{ }^{\circ} \mathrm{C}$ ) as described by Li et al. (2015), different pH values (4.0-11.0, at intervals of 1.0) and various tolerances to $\mathrm{NaCl}(0 \%-10 \%[\mathrm{w} / \mathrm{v}]$, at intervals of $1 \%)$. As reported by Gomori (1955), the $\mathrm{pH}$ values were adjusted using the following buffers: citric acid/sodium citrate $(\mathrm{pH} 4.0-5.5), \mathrm{Na}_{2} \mathrm{HPO}_{4} / \mathrm{NaH}_{2} \mathrm{PO}_{4}(\mathrm{pH}$ 
6.0-8.0), $\mathrm{Na}_{2} \mathrm{CO}_{3} / \mathrm{NaHCO}_{3}(\mathrm{pH} 8.0-9.5)$ and $\mathrm{Na}_{2} \mathrm{HPO}_{4} / \mathrm{NaOH}$ (pH 10.0-11.0). Anaerobic growth was examined after the novel strain was incubated on TSA plates at $30{ }^{\circ} \mathrm{C}$ for 1 week in anaerobic jars filled with $\mathrm{N}_{2} / \mathrm{CO}_{2}(80: 20, \mathrm{v} / \mathrm{v})$ (Gerhardt et al. 1981). Catalase and oxidase activities were measured as recommended by Smibert and Krieg (1994). The oxidase activity of the novel strain was examined by determining whether a color change to purple occurred after using $1 \%(\mathrm{w} / \mathrm{v})$ tetramethyl-p-phenylenediamine. Gram staining was tested according to the description of Jenkins (2003). Other biochemical and physiological tests were performed using API 20E, API 20NE, and API 50CHB/E kits (bioMérieux) and the Biolog $\mathrm{GN}_{2}$ MicroPlate according to the manufacturer's instructions. The strains tested in these analyses were cultured on TSA at $30^{\circ} \mathrm{C}$ for $24 \mathrm{~h}$ and then were harvested during the exponential phase.

\section{Chemotaxonomic analyses}

The strains were cultured on TSA at $30{ }^{\circ} \mathrm{C}$ for $24 \mathrm{~h}$ and then were harvested during the exponential phase. Fatty acids were analyzed using the Microbial Identification System, Sherlock version 6.0 (Sasser 1990).

\section{Pathogenicity determination}

4 year-old poplar trees were chosen for inoculation at the poplar nursery in Puyang City, Henan Province. The strain was cultured on nutrient agar plates at $30^{\circ} \mathrm{C}$ for 24 hours, then were washed and centrifuged to pellet the cells. The collected cells were diluted in SDW to $10^{8} \mathrm{CFU} / \mathrm{ml}$. After the bark was surface sterilized with 75 $\%$ ethanol, $1 \mathrm{~cm}$-long cross-wounds were cut into the bark with a sterilized knife. A total of $100 \mu \mathrm{l}$ of bacterial suspension was delivered to the inoculation point. Negative control plants were inoculated with sterile distilled water. The results of pathogenicity tests were recorded 7, 14, and 21 days after inoculation.

\section{Results And Discussion}

\section{Morphological and phenotypic characteristics}

Transmission electron microscopy showed that the cells were short rods or globose, with peritrichous flagella and $0.5-1.0 \times 0.8-2.5 \mu \mathrm{m}$ in size (Fig. S5). The colonies were white, circular, and approximately 1-2 $\mathrm{mm}$ in diameter after $48 \mathrm{~h}$ of growth at $30^{\circ} \mathrm{C}$ on TSA. The strain is a motile, facultative anaerobic bacterium with positive catalase and negative oxidase activities. The detailed differentiated biochemical and physiological characteristics of the novel strain and close genera are listed in Tables 1.

\section{Phylogenetic analysis}

The 16S rRNA gene sequencing of novel strain $\mathrm{L}_{3}-3 \mathrm{HA} \mathrm{A}^{\top}$ shares the highest sequence similarity with Brenneriagoodwinii FRB $141^{\top}$ (95.5 \%) and lower sequence similarity values (95.4\%) with other validly published species. In ML and NJ phylogenetic trees based on 16S rRNA gene sequencing (Fig. 1, Fig. S1), the novel strain formed an dependent lineage, separated from those of five Pectobacteriaceae genera and other family reference species of Izhakiella, Pantoea and Mixta. And in the ML and NJ phylogenetic trees based on MLSA data (Fig. 2, Fig. S2), the novel strain clustered into a distinct branch from other genera in the present 
study, suggesting that the novel strain should represent a novel species in a novel genus within the Pectobacteriaceae family.

\section{Genomic characteristics}

The sequencing depth of coverage was $130^{\prime}$. The genome of strain $L 3-3 H A^{\top}$ is $5.89 \mathrm{Mb}$ in size across 47 contigs (N50 is 322317 bp), including 5,052 coding genes, 10 rRNAs, 74 tRNAs, 9 other RNAs and 197 pseudogenes. The DNA G+C content is $57.1 \%$. Also, the strain $L 3-3 H A^{\top}$ formed a distinct branch from the five genera within the Pectobacteriaceae family clades in the phylogenomic tree (Fig. 3), demonstrating that the novel strain represents a novel species in a novel genus within the family Pectobacteriaceae.

The novel strain showed 72.43-77.56 \% ANI values with the reference strains of the family Pectobacteriaceae and Erwiniaceae, and the detailed data were shown in Table 2. These values were all lower than the

proposed species boundary ANI cut-off (95-96\%) (Fu et al. 2012). The dDDH values between L3-3HA ${ }^{\top}$ strain and the same reference strains used in ANI analysis were $13 \%-22 \%$, lower than the $70 \%$ cut-off for species determination (Table 2) (Wayne et al. 1987).

The AAI analysis results revealed that the five reference type strains of the genera Lonsdalea, Brenneria, Dickeya, Pectobacterium, Sodalis shared $64 \%-81 \%$ AAl values with each other. The novel strain showed $64.2 \%-74.9 \%$ AAl values with these five reference type strains (Table S3), lower than the AAI values among the five reference type strains. These results supported that the novel isolate represents a novel species in a novel genus in family Pectobacteriaceae.

Genome comparison shows that the novel strain ( $5.89 \mathrm{Mb}$ ) has large genome size, comprises 5,052 coding genes, $1,907,1,617,990$, and 1,045 more genes than the reference strains $L$. quercina ATCC $29281^{\top}, B$. salicis DSM $30166^{\top}$, P. carotovorum LMG $2404^{\top}$ and D. chrysanthemi NCPPB $402^{\top}$. L. quercina and B. salicis are pathogens of Quercus spp. and Salix spp., respectively (Brady et al. 2012; Sakamoto et al. 1999), and they have a small genome size (3.9-4.0 Mb) with a single host compared with $P$. carotovorum and $D$. chrysanthemi. The plant pathogens $P$. carotovorum and $D$. chrysanthemi, with a diverse host range (Toth et al. 2003), have a large genome (4.8 $\mathrm{Mb}$ in size), which is seemingly important to adopt diverse hosts for the bacterial pathogen. Thus, the novel strains may be a multihost bacterial plant pathogen.

In the present study, 181 virulence genes were found in the genome of the novel strain, including 15 "loss of pathogenicity" genes, 155 "reduced virulence" genes and 15 "increased virulence" genes. The results indicated that the novel strain is a potential pathogen of plants, although it is not a pathogen of the poplar tree. And in total, 145 carbohydrate-active enzymes were found from the genome sequence of the novel strain. Eleven enzymes were found to be associated with degradation, including 2 cellulases $₫ 8$ chitinases and 1 pectin lyase, which are important enzymes for the pathogens of plants.

\section{Chemotaxonomic characteristics}

The major fatty acids detected in the novel strain were $\mathrm{C}_{14: 0}, \mathrm{C}_{16: 0}, \mathrm{C}_{17: 0}$ cyclo and $\mathrm{C}_{19: 0}$ cyclo $[8 \mathrm{c}$. The percentages of the peak area for fatty acids of the novel and reference strains are listed in Table S2. The 
amount of $\mathrm{C}_{17: 0}$ cyclo and $\mathrm{C}_{19: 0}$ cyclo $\square 8 \mathrm{c}$ can be used to distinguish the novel strain from the five reference strains used in the present study.

\section{Pathogenicity test}

The results of pathogenicity experiment showed that the novel strain did not show pathogenicity to poplar trees.

\section{Taxonomic conclusion}

In the trees based on the 16S rRNA gene and MLSA data, the strains of the genus Brenneria were clustered into two separate clades, indicating that the taxonomy of the Brenneria species may be polyphyletic. Although the Brenneria strains clustered together in the phylogenomic trees, the Brenneria species were still divided into two clades. Therefore, we speculated that B. alni, B. corticis, B. goodwinnii, $B$. nigrifluens, and $B$. populi may represent a novel genus within the family Pectobacteriaceae.

The 16S rRNA gene and MLSA analysis revealed that the novel strain belongs to a novel species in a novel genus within the family Pectobacteriaceae, which is also supported by AAl, fatty acid and phyologenomic analyses. Moreover, many physiological and biochemical characteristics can be used to distinguish the novel strain from close genera of the family Pectobacteriaceae (detailed in Table 2). Based on those data, the L3-3HA ${ }^{\top}$ strain represents a novel species of a novel genus in the Pectobacteriaceae family, for which the name Affinibrenneria salicis gen nov. sp. nov. is proposed.

\section{Description of Affinibrenneria gen. nov.}

Affinibrenneria (Af.fi.ni.bren.ne'ri.a. L. masc. adj. affinis associated with, adjacent; N.L. fem. n. Brenneria, a bacterial genus; N.L. fem. n. Affinibrenneria, a genus associated with Brenneria).

Gram-negative, facultative anaerobic, motile, oxidase-negative, and catalase-positive. Growth occurs between $4{ }^{\circ} \mathrm{C}$ and $50{ }^{\circ} \mathrm{C}$ and at pH $6-8$ and $0 \%-5 \%$ salinity. The cells are also positive for $\beta$-galactosidase activity and negative for the activities of urease and gelatinase and the production of $\mathrm{H}_{2} \mathrm{~S}$ and indole. Citrate is not utilized, and nitrates are not reduced to nitrites. The main fatty acids are $\mathrm{C}_{14: 0}, \mathrm{C}_{16: 0}, \mathrm{C}_{17: 0}$ cyclo and $\mathrm{C}_{19: 0}$ cyclo $[8$ c. The DNA G+C content is $57.1 \%$, and the type species is Affinibrenneria salicis. Affinibrenneria salicis gen. nov. sp. nov. is a member of the family Pectobacteriaceae.

\section{Description of Affinibrenneria salicis sp. nov.}

Affinibrenneria salicis (sa'li.cis. L. gen. n. salicis of Salix matsudana)

The cells are Gram-negative, facultative anaerobic, motile, short rod or globose with peritrichous flagella. The colonies are circular, convex with complete margins. The cells show negative activities for arginine dihydrolase, lysine decarboxylase, ornithine decarboxylase, tryptophan deaminase, urease, and gelatinase and are negative for the production of $\mathrm{H}_{2} \mathrm{~S}$ and indole. The cells do not utilize citrate and do not reduce nitrates to nitrites. The cells are positive for acid production from d-arabinose, $d$-ribose, $d$-galactose, $d$ - 
glucose, d-fructose, d-mannose, methyl $a$-d-mannopyranoside, methyl $a$-d-glucopyranoside, $n$ acetylglucosamine, amygdalin, arbutin, esculin ferric citrate, salicin, d-cellobiose, d-maltose, d-lactose, $d$ melibiose, $d$-saccharose, $d$-trehalose, $d$-raffinose, gentiobiose, $d$-turanose, d-lyxose and d-arabitol (API 50CH). The cells are also positive for the utilization of $a$-cyclodextrin, dextrin, glycogen, Tween $80, n$-acetyl-dgalactosamine, $n$-acetyl-d-glucosamine, adonitol, l-arabinose, d-arabitol, d-cellobiose, i-erythritol, d-fructose, lfucose, $\mathrm{d}$-galactose, gentiobiose, $a$-d-glucose, $m$-inositol, $a$-d-lactose, lactose, maltose, $d$-mannitol, $d$ mannose, $d$-melibiose, $\beta$-methyl d-glucoside, d-psicose, d-raffinose, l-rhamnose, d-sorbitol, sucrose, $d$ trehalose, turanose, xylitol, methyl pyruvate, mono-methyl succinate, cis-aconitic acid, formic acid, $d$ galacturonic acid, d-gluconic acid, d-glucosaminic acid, d-glucuronic acid, $a$-hydroxybutyric acid, $a$-keto butyric acid, $a$-keto glutaric acid, d,-l-lactic acid, propionic acid, succinic acid, succinamic acid, I-asparagine, Iaspartic acid, I-glutamic acid, I-serine, inosine, uridine, thymidine, 2,3-butanediol, glycerol, glucose-1phosphate and glucose-6-phosphate $\left(\right.$ Biolog $\mathrm{GN}_{2}$ ). The main fatty acids are $\mathrm{C}_{14: 0}, \mathrm{C}_{16: 0}, \mathrm{C}_{17: 0}$ cyclo and $\mathrm{C}_{19: 0}$

cyclo $\left[8 \mathrm{c}\right.$. The DNA G+C content is $57.1 \%$. And the type strain is $L 3-3 H A^{\top}\left(=C F C C 15588^{\top}=L M G 31209^{\top}\right)$ isolated from the bark of Salix matsudana canker. The GenBank/EMBL/DDBJ accession numbers for the 16S rRNA gene and whole-genome sequences of L3-3HA ${ }^{\top}$ are MN036523 and NZ VYKJ00000000, respectively.

\section{Declarations}

Acknowledgments We are grateful to Mr. Hai-ming Wang of Heze Forest Protection Station for his help with sample collection.

Author contributions BDR performed the experiments and wrote the manuscript; $\mathrm{XH}$ and WGM performed the study and analyzed the data.PCG and LY guided the experiments and revised the manuscript.

\section{Funding information}

This study was financially supported by the National Infrastructure of Microbial Resources (NIMR-2020-7) from the Ministry of Science and Technology of the People's Republic of China.

\section{Compliance with ethical standards}

Conflicts of interest The authors declare that there are no conflicts of interest.

Ethical statement This article does not contain any studies with human participants or animals performed by any of the authors.

\section{References}

Adeolu M, Alnajar S, Naushad S, Gupta RS (2016) Genome-based phylogeny and taxonomy of the 'Enterobacteriales': proposal for Enterobacterales ord. nov. divided into the families Enterobacteriaceae, Erwiniaceae fam. nov., Pectobacteriaceae fam. nov., Yersiniaceae fam. nov., Hafniaceae fam. nov., Morganellaceae fam. nov., and Budviciaceaefam. nov. Int J Syst Evol Microbiol 66: 5575-5599. 
Baker GC, Smith JJ, Cowan DA (2003) Review and reanalysis of domain specific 16S primers. J Microbiol Methods 55:541-555.

Brady CL, Cleenwerck I, Denman S, Venter SN, Rodríguez-Palenzuela P, Coutinho TA, De Vos P (2012) Proposal to reclassify Brenneria quercina (Hildebrand and Schroth 1967) Hauben, et al. 1999 into a new genus, Lonsdalea gen. nov., as Lonsdalea quercina comb. nov., descriptions of Lonsdalea quercina subsp. quercina comb. nov., Lonsdalea quercina subsp. iberica subsp. nov. and Lonsdalea quercina subsp. britannica subsp. nov., emendation of the description of the genus Brenneria, reclassification of Dickeya dieffenbachiae as Dickeyadadantii subsp. dieffenbachiae comb. nov., and emendation of the description of Dickeya dadantii. Int J Syst Evol Microbiol 62: 1592-1602.

Brady C, Cleenwerck I, Venter S, Coutinho T, and De Vos P (2013) Taxonomic evaluation of the genus Enterobacter based on multilocus sequence analysis (MLSA): proposal to reclassify E. nimipressuralis and E. amnigenus into Lelliottia gen. nov. as Lelliottia nimipressuralis comb. nov. and Lelliottia amnigena comb. nov., respectively, E. gergoviae and E. pyrinus into Pluralibacter gen. nov. as Pluralibacter gergoviae comb. nov. and Pluralibacter pyrinus comb. nov., respectively, E. cowanii, E. radicincitans, E. oryzae and E. arachidis into Kosakonia gen. nov. as Kosakonia cowanii comb. nov., Kosakonia radicincitans comb. nov., Kosakonia oryzae comb. nov. and Kosakonia arachidis comb. nov., respectively, and E. turicensis, E. helveticus and E. pulveris into Cronobacter as Cronobacter zurichensis nom. nov., Cronobacter helveticus comb. nov. and Cronobacter pulveris comb. nov., respectively, and emended description of the genera Enterobacter and Cronobacter. Syst Appl Microbiol. 36: 309-319.

Brady C, Hunter G, Kirk S, Arnold D, Denman S (2014) Description of Brenneria roseae sp. nov. and two subspecies, Brenneria roseae subspecies roseae ssp. nov and Brenneria roseae subspecies americana ssp. nov. isolated from symptomatic oak. Syst Appl Microbiol 37:396-401.

Buchfink B, Xie C, Huson DH (2015) Fast and sensitive protein alignment using Diamond. Nature Methods 12: $59-60$.

Chun J, Oren A, Ventosa A, Christensen H, Arahal DR, da Costa MS, Rooney AP, Yi H, Xu XW, De Meyer S, Trujillo ME (2018) Proposed minimal standards for the use of genome data for the taxonomy of prokaryotes. Int J Syst Evol Microbiol 68:461-466.

Dale C, Maudlin I (1999) Sodalis gen. nov. and Sodalis glossinidius sp. nov., a microaerophilic secondary endosymbiont of the tsetse fly Glossina morsitans morsitans. Int J Syst Bacteriol 49: 267-275.

Denman S, Brady C, Kirk S, Cleenwerck I, Venter S, Coutinho T, De Vos P (2012) Brenneria goodwinii sp. nov., associated with acute oak decline in the UK. Int J Syst Evol Microbiol 62:2451-2456.

Edgar RC (2004) Muscle: multiple sequence alignment with high accuracy and high throughput. Nucleic Acids Res 32:1792-1797.

Fu LM, Niu BF, Zhu ZW, Wu ST, Li WZ (2012) CD-HIT: accelerated for clustering the next generation sequencing data. Bioinformatics 28: 3150-3152. 
Gardan L, Gouy C, Christen R, Samson R (2003) Elevation of three subspecies of Pectobacterium carotovorum to species level: Pectobacterium atrosepticum sp. nov., Pectobacterium betavasculorum sp. nov. and Pectobacterium wasabiaesp. nov. Int J Syst Evol Microbiol 53:381-391.

Gerhardt P, Murray RGE, Costilow RN, Nester EW, Wood WA, Krieg NR, Phillips B (1981) Manual of methods for general bacteriology. Washington, DC: American Society for Microbiology.

Gomori G (1955) Preparation of buffers for use in enzyme studies. In: Colowick SP and Kaplan NO (editors). Methods in enzymology. NY: Academic Press, pp 138-146.

Goris J, Konstantindis KT, Klappenbach JA, Coenye T, Vandamme P, Tiedje JM (2007) DNA-DNA hybridization values and their relationship to whole-genome sequence similarities. Int J Syst Evol Microbiol 57:81-91.

Guindon S, Dufayard JF, Lefort V, Anisimova M, Hordijk W, Gascuel O (2010) New algorithms and methods to estimate maximum-likelihood phylo-genies: assessing the performance of PhyML 3.0. Syst Biol 59:307-321.

Hauben L, Moore ER, Vauterin L, Steenackers M, Mergaert J, Verdonck L, Swings J (1998) Phylogenetic position of phytopathogens within the Enterobacteriaceae. Syst Appl Microbiol 21: 384-397.

Hugouvieux-Cotte-Pattat N, Jacot-des-Combes C, Briolay J (2019) Dickeya lacustris sp. nov., a water-living pectinolytic bacterium isolated from lakes in France. Int J Syst Evol Microbiol 69:721-726.

Hugouvieux-Cotte-Pattat N, Brochier-Armanet C, Flandrois JP, Reverchon S (2020) Dickeya poaceiphila sp. nov., a plant-pathogenic bacterium isolated from sugar cane (Saccharum officinarum). Int J Syst Evol Microbiol 70:4508-4514.

Jenkins D, Richard MG, Daigger GT (2003) Manual on the causes and control of activated sludge bulking and foaming, and other solids separation problems. London: IWA Publishing.

Khayi S, Cigna J, Chong TM, Quêtu-Laurent A, Chan KG, Hélias V, Faure D. (2016) Transfer of the potato plant isolates of Pectobacterium wasabiae to Pectobacterium parmentieri sp. nov. Int J Syst Evol Microbiol 66:5379-5383.

Konstantinidis KT and Tiedje JM (2005) Towards a genome-based taxonomy for prokaryotes. J Bacteriol 187: 6258-6264.

Kumar S, Stecher G, Tamura K (2016) MEGA7: Molecular Evolutionary Genetics Analysis Version 7.0 for Bigger Datasets. Mol Biol Evol 33:1870-1874.

Lane DJ (1991) 16S/23S rRNA sequencing. In: Stackebrandt E, Goodfellow M (editor). Nucleic acid techniques in bacterial systematics. NY: Wiley, pp 115-175.

Li Y, Fang W, Xue H, Liang WX, Wang LF, Tian GZ, Wang XZ, Lin CL, Li X, Piao CG (2015) Brenneria populi sp. nov., isolated from symptomatic bark of Populusx euramericana canker. Int J Syst Evol Microbiol 65: 432- 
Li Y, Song LM, Guo MW, Wang LF, Liang WX (2016) Description of Sphingobacterium populi sp. nov., isolated from bark of Populusx euramericana. Int J Syst Evol Microbiol 66:3456-3462.

Li Y, Xu GT, Piao CG, Chang JP, Guo LM, Yang XQ, Piao CG (2017a) Sphingobacterium cortices sp. nov., isolated from bark of Populus $\times$ euramericana. Int J Syst Evol Microbiol 67: 3860-3864.

Li Y, Xue H, Guo LM, Koltay A, Palacio-Bielsa A, Chang JP, Xie SJ, Yang XQ (2017b) Elevation of three subspecies of Lonsdalea quercina to species level: Lonsdalea britannica sp. nov., Lonsdalea iberica sp. nov. and Lonsdalea populi sp. nov. Int J Syst Evol Microbiol 67:4680-4684.

Li Y, Zheng MH, Wang HM, Lin CL, Wang XZ (2019) Brenneria corticis sp. nov., isolated from symptomatic bark of Populus $\times$ euramericana canker. Int J Syst Evol Microbiol 69:63-67.

Lombard V, Golaconda Ramulu H, Drula E, Coutinho PM, Henrissat B (2014) The carbohydrate-active enzymes database (CAZy) in 2013. Nucleic Acids Res 42: D490-D495.

Meier-Kolthoff JP, Auch AF, Klenk HP, Göker M (2013) Genome sequence-based species delimitation with confidence intervals and improved distance functions. BMC Bioinformatics 14:60.

Oulghazi S, Pédron J, Cigna J, Lau YY, Moumni M, Van Gijsegem F, Chan KG, Faure D (2019) Dickeya undicola sp. nov., a novel species for pectinolytic isolates from surface waters in Europe and Asia. Int J Syst Evol Microbiol 69:2440-2444.

Parkinson N, DeVos P, Pirhonen M, Elphinstone J (2014) Dickeya aquatica sp. nov., isolated from waterways. Int J Syst Evol Microbiol 64:2264-2266.

Parte AC (2018) LPSN - List of prokaryotic names with standing in nomenclature (bacterio.net), 20 years on. Int J Syst Evol Microbiol 68:1825-1829.

Portier P, Pédron J, Taghouti G, Fischer-Le Saux M, Caullireau E, Bertrand C, Laurent A, Chawki K, Oulgazi S, Moumni M, Andrivon D, Dutrieux C, Faure D, Hélias V, Barny MA (2019) Elevation of Pectobacterium carotovorum subsp. odoriferum to species level as Pectobacterium odoriferum sp. nov., proposal of Pectobacterium brasiliense sp. nov. and Pectobacterium actinidiae sp. nov., emended description of Pectobacterium carotovorum and description of Pectobacterium versatile sp. nov., isolated from streams and symptoms on diverse plants. Int J Syst Evol Microbiol 69:3214-3223.

Richter M and Rosselló-Móra R (2009) Shifting the genomic gold standard for the prokaryotic species definition. PNASci 10:19126-19131.

Sakamoto Y, Takikawa Y, Sasaki K (1999) Occurrence of watermark disease of willows in Japan. Plant Pathol 48: 613-619. 
Samson R, Legendre JB, Christen R, Fischer-Le Saux M, Achouak W, Gardan L (2005) Transfer of Pectobacterium chrysanthemi (Burkholder et al. 1953) Brenner et al. 1973 and Brenneria paradisiaca to the genus Dickeya gen. nov. as Dickeyachrysanthemi comb. nov. and Dickeya paradisiaca comb. nov. and delineation of four novel species, Dickeya dadantii sp. nov., Dickeya dianthicola sp. nov., Dickeya dieffenbachiae sp. nov. and Dickeya zeae sp. nov. Int J Syst Evol Microbiol 55: 1415-1427.

Santos-Garcia D, Silva FJ, Morin S, Dettner K, Kuechler SM (2017) The all-rounder Sodalis: A new bacteriomeassociated endosymbiont of the Lygaeoid bug Henestaris halophilus (Heteroptera: Henestarinae) and a critical examination of its evolution. Genome Biol Evol 9:2893-2910.

Sasser M (1990) Identification of bacteria by gas chromatography of cellular fatty acids, MIDI Technical Notes 101. Newark, DE: MIDI Inc.

Smibert RM, Krieg NR (1994) Phenotypic characterization. In: Gerhardt P, Murray RGE, Wood WA and Krieg NR (editors). Manual of methods for general and microbiology. Washington, DC: American Society for Microbiology pp 607-654.

Tian Y, Zhao Y, Yuan X, Yi J, Fan J, Xu Z, Hu B, De Boer SH, Li X (2016) Dickeya fangzhongdai sp. nov., a plant-pathogenic bacterium isolated from pear trees (Pyrus pyrifolia). Int J Syst Evol Microbiol 66:28312835.

Toth IK, Bell KS, Holeva MC, Birch PRJ (2003) Soft rot Erwinia: from genes to genomes. Mol Plant Pathol 4:17-30.

Urban M, Cuzick A, Seager J, Wood V, Kim R, Venkatesh SY, De Silva N, Martinez M C, Pedro H, Yates AD, Hassani-Pak K, Hammond-Kosack KE (2020) PHI-base: the pathogen-host interactions database.Nucleic Acids Research 48: D613-D620.

van der Wolf JM, Nijhuis EH, Kowalewska MJ, Saddler GS, Parkinson N, Elphinstone JG, Pritchard L, Toth IK, Lojkowska E, Potrykus M, Waleron M, de Vos P, Cleenwerck I, Pirhonen M, Garlant L, Hélias V, Pothier JF, Pflüger V,Duffy B, Tsror L, Manulis S (2014) Dickeya solani sp. nov., a pectinolytic plant-pathogenic bacterium isolated from potato (Solanum tuberosum). Int J Syst Evol Microbiol 64:768-774.

Waldee EL. Comparative studies of some peritrichous phytopathogenic bacteria. lowa State Journal of Science 1945; 19: 435-484.

Wang X, He SW, Guo HB, Han JG, Thin KK, Gao JS, Wang Y, Zhang XX (2020) Dickeya oryzae sp. nov., isolated from the roots of rice. Int J Syst Evol Microbiol 70:4171-4178.

Wayne LG, Brenner DJ, Colwell RR, Grimont PAD,Moore LH, Moore WEC, Murray RGE, Stackebrandt E, Starr MP, Trüper HG (1987) Report of the ad hoc committee on reconciliation of approaches to bacterial systematics. Int J Syst Bacteriol 37:463-464.

Yoon SH, Ha SM, Kwon S, Lim J, Kim Y, Seo H, Chun J (2017) Introducing EzBioCloud: a taxonomically united database of 16 S rRNA gene sequences and whole-genome assemblies. Int J Syst Evol Microbiol 


\section{Tables}

Table 1. Biochemical and physiological characteristics that distinguish the novel strain from five close genera of the family Pectobacteriaceae

Taxa: 1, Affinibrenneria gen. nov; 2, Lonsdalea; 3, Brenneria; 4, Dickeya; 5, Pectobacterium; 6, Sodalis. +, positive; -, negative; v, variable reaction; nd, not determined. ${ }^{a}$ Except B.paradisiaca; ${ }^{b}$ Except B. salicis and B.quercina; ${ }^{\mathrm{C}}$ Except B.nigrifluens and B.populi; ${ }^{\mathrm{d}}$ Except D.dadantii and D.undicola; ${ }^{\mathrm{e}}$ Except D.dieffenbachiae; ${ }^{\mathrm{f}}$, Type species of the genus, Pectobacterium carotovorum, the data were from Brady (2012). g, the data were from Dale (1999).*, column 2, data were from Li et al. 2017b; Brady et al. 2012; column 3, data were from Hauben et al. 1999; Li et al. 2019; Denman et al. 2012; Li et al. 2015; Brady et al. 2014; column 4, data were from Samson et al. 2005; Parkinson et al. 2014; Tian et al. 2016; Hugouvieux-Cotte-Pattat et al. 2019 and 2020; Wang et al. 2020; van der Wolf et al. 2014; Oulghazi et al. 2019; column 5, data were from Hauben et al. 1999; Gardan et al. 2003; Portier et al. 2019; Khayi et al. 2016; column 6, data were from Santos-Garcia et al. 2017.

\begin{tabular}{|c|c|c|c|c|c|c|}
\hline Characteristic & 1 & 2 & 3 & 4 & $5^{f}$ & $6^{9}$ \\
\hline$\beta$-Galactosidase & + & - & $\mathrm{v}$ & nd & + & - \\
\hline $\begin{array}{l}\text { Citrate } \\
\text { utilization }\end{array}$ & - & + & - & nd & + & nd \\
\hline $\mathrm{H}_{2} \mathrm{~S}$ production & - & - & - & nd & $\mathrm{v}$ & nd \\
\hline Indole & - & - & $-\mathrm{a}$ & nd & - & - \\
\hline Gelatinase & - & - & - & nd & + & - \\
\hline \multicolumn{7}{|l|}{ Acid from: } \\
\hline Amygdalin & + & - & $\mathrm{v}$ & + & + & nd \\
\hline l-Arabinose & - & - & $++^{\mathrm{b}}$ & + & + & - \\
\hline Cellobiose & + & - & $\mathrm{v}$ & + & + & nd \\
\hline Gentiobiose & + & - & $\mathrm{v}$ & $-d$ & + & nd \\
\hline Melibiose & + & - & $\mathrm{v}$ & $+^{\mathrm{e}}$ & + & - \\
\hline $\begin{array}{l}\text { Methyl } \alpha \text {-d- } \\
\text { glucopyranoside }\end{array}$ & + & + & $-\mathrm{C}$ & - & - & - \\
\hline l-Rhamnose & - & - & $\mathrm{v}$ & $\mathrm{v}$ & + & - \\
\hline d-Xylose & - & - & $\mathrm{v}$ & + & + & - \\
\hline $\mathrm{G}+\mathrm{C}(\%)^{*}$ & 57.1 & 54.5-55.6 & $50.1-56.2$ & 53.1-59.5 & $50.4-56.1$ & $\begin{array}{l}44.5- \\
57.5\end{array}$ \\
\hline Host* & $\begin{array}{l}\text { Salix } \\
\text { matsudana }\end{array}$ & $\begin{array}{l}\text { Oak and } \\
\text { Populus } \times \\
\text { euramericana }\end{array}$ & $\begin{array}{l}\text { Oak, Populus } \times \\
\text { euramericana, Juglans } \\
\text { regia, Salix spp, Alnus } \\
\text { and Musa paradisiaca }\end{array}$ & $\begin{array}{l}\text { Water, soft } \\
\text { rot and wilt li } \\
\text { of various } t z \\
\text { plants }\end{array}$ & $\begin{array}{l}\text { Water and wide range of host plants, } \\
\text { ke Actinidia chinensis, Solanum } \\
\text { uberosum, Zantedeschia } \\
\text { ethiopica and Eutrema wasabi }\end{array}$ & $\begin{array}{l}\text { Insects } \\
\text { and } \\
\text { human } \\
\text { wound }\end{array}$ \\
\hline
\end{tabular}

Table 2. Average nucleotide identity (ANI) and genome-to-genome distance calculator (GGDC) from the novel and reference strains of $t$ family Pectobacteriaceae and Erwiniaceae.

DDBJ/EMBL/GenBank genome accession numbers: Lonsdalea quercina ATCC 29281 ${ }^{\mathrm{T}}$, NZFNQS01000000; Brenneria salicis ATCC $15712^{\mathrm{T}}$, NZMJMA01000000; Pectobacterium carotovorum DSM 30168 ${ }^{\mathrm{T}}$, NZFQWI01000025; Sodalis praecaptivus HS ${ }^{\mathrm{T}}$, CP006569; Dickeya chrysanthemi NCPPB 402 ${ }^{\mathrm{T}}$, NZCM001974; Mixta calida DSM 22759T ${ }^{\mathrm{T}}$ NZCP026378; Pantoea agglomerans C410P1 ${ }^{\mathrm{T}}$, NZCP016889; Pantoea dispersa CCUG 25232 ${ }^{\mathrm{T}}$, NZVXKA01000001; Izhakiella capsodis N6PO6 ${ }^{\mathrm{T}}$, NZFOVC01000030. 


\begin{tabular}{|c|c|c|c|c|}
\hline \multirow[t]{2}{*}{ Strain } & \multirow[t]{2}{*}{ ANI } & \multirow{2}{*}{$\begin{array}{l}\text { GGDC } \\
\text { DDH1 }\end{array}$} & \multirow{2}{*}{$\begin{array}{l}\text { GGDC } \\
\text { DDH2 }\end{array}$} & \multirow{2}{*}{$\begin{array}{l}\text { GGDC } \\
\text { DDH3 }\end{array}$} \\
\hline & & & & \\
\hline Lonsdalea quercina ATCC $29281^{\mathrm{T}}$ & 75.70 & 16.5 & 21.0 & 16.4 \\
\hline Brenneria salicis ATCC $15712^{\mathrm{T}}$ & 76.45 & 17.1 & 21.3 & 16.9 \\
\hline Pectobacterium carotovorum DSM $30168^{\mathrm{T}}$ & 75.92 & 15.9 & 20.8 & 15.9 \\
\hline Sodalis praecaptivus $\mathrm{HS}^{\mathrm{T}}$ & 74.60 & 14.5 & 20.5 & 14.7 \\
\hline Dickeya chrysanthemi NCPPB $402^{\mathrm{T}}$ & 75.93 & 15.8 & 21.0 & 15.9 \\
\hline Mixta calida DSM $22759^{\mathrm{T}}$ & 77.56 & 15.6 & 20.5 & 15.6 \\
\hline Pantoea agglomerans $\mathrm{C} 410 \mathrm{P} 1^{\mathrm{T}}$ & 73.91 & 14.1 & 20.4 & 14.4 \\
\hline Pantoea dispersa CCUG $25232^{\mathrm{T}}$ & 74.75 & 14.8 & 20.2 & 14.9 \\
\hline Izhakiella capsodis $\mathrm{N}^{2} \mathrm{PO}^{\mathrm{T}}$ & 72.43 & 13.4 & 19.9 & 13.7 \\
\hline
\end{tabular}

Figures 


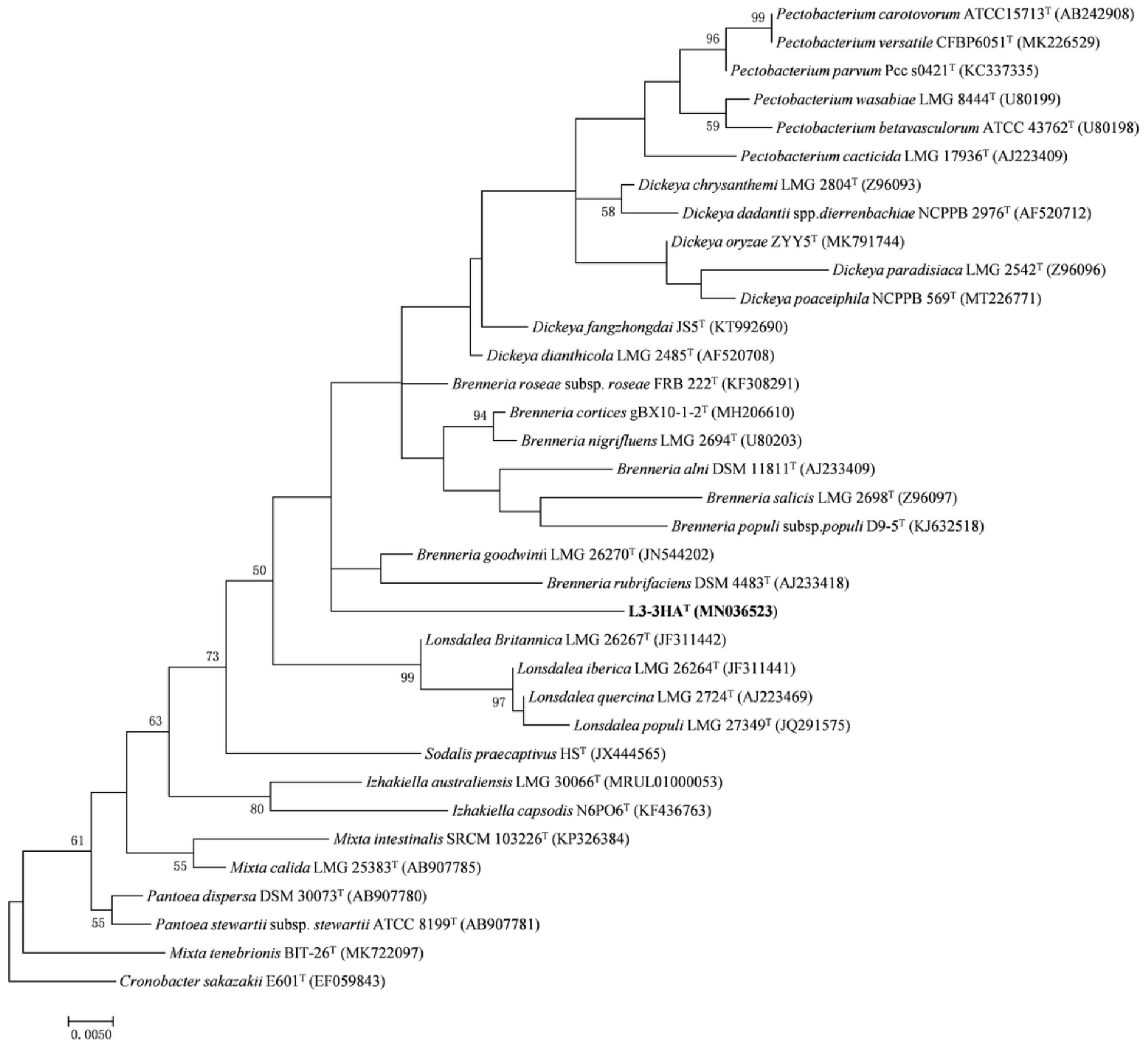

\section{Figure 1}

Maximum-likelihood tree based on 16S rRNA gene sequences showing the relationship between the novel species and closely related species. Bootstrap values after 1,000 replicates are expressed as percentages. Cronobacter sakazakii is included as an outgroup. Bar, 0.01 substitutions per site. 


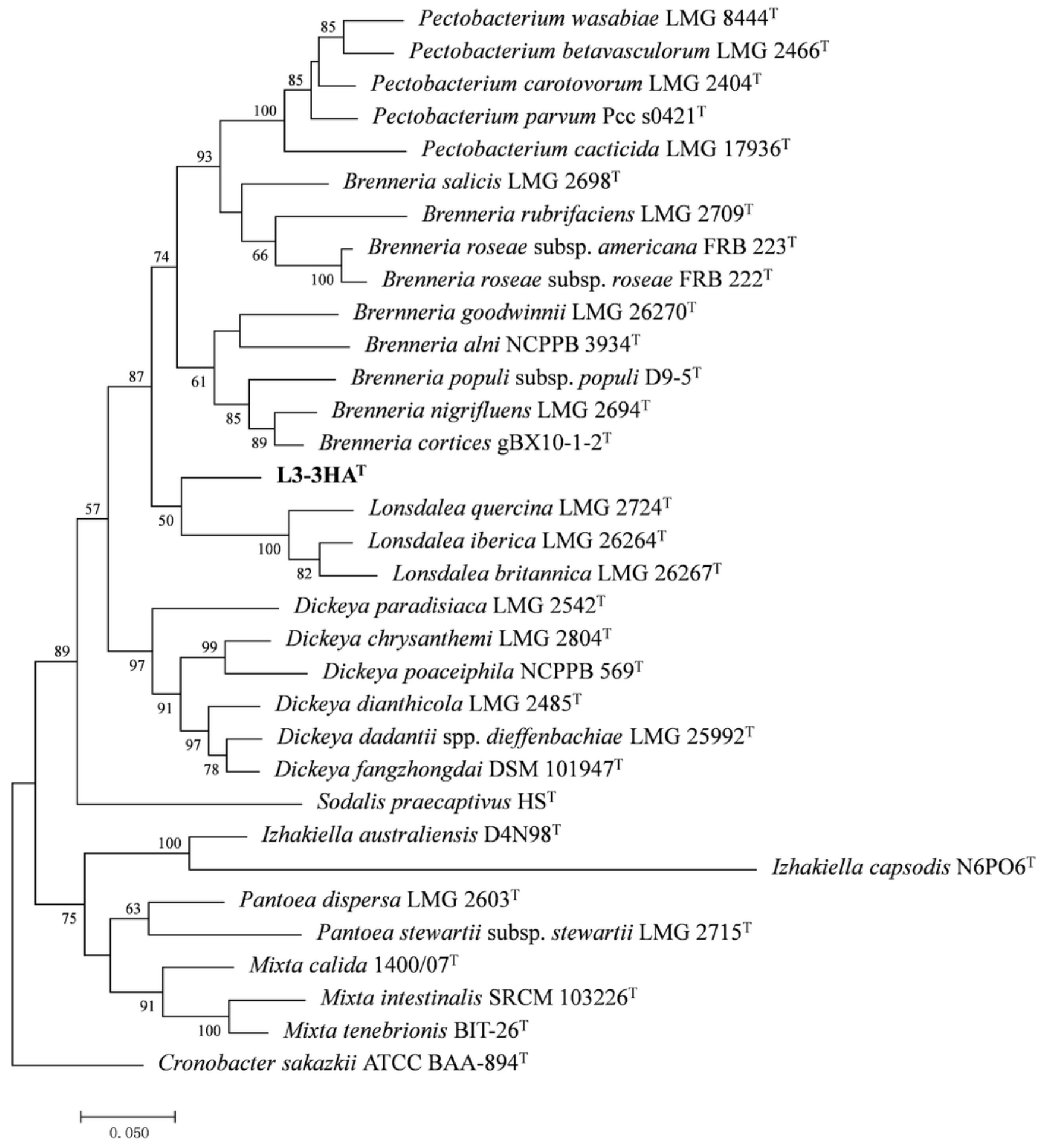

Figure 2

Maximum-likelihood tree based on concatenated partial gyrB, rpoB, atpD, infB gene sequences of the type strains in the genera Lonsdalea, Brenneria, Dickeya, Pectobacterium, Sodalis, Izhakiella, Pantoea and Mixta. Bootstrap values after 1,000 replicates are expressed as percentages. Cronobacter sakazakii is included as an outgroup. Bar, 0.050 substitutions per site. 


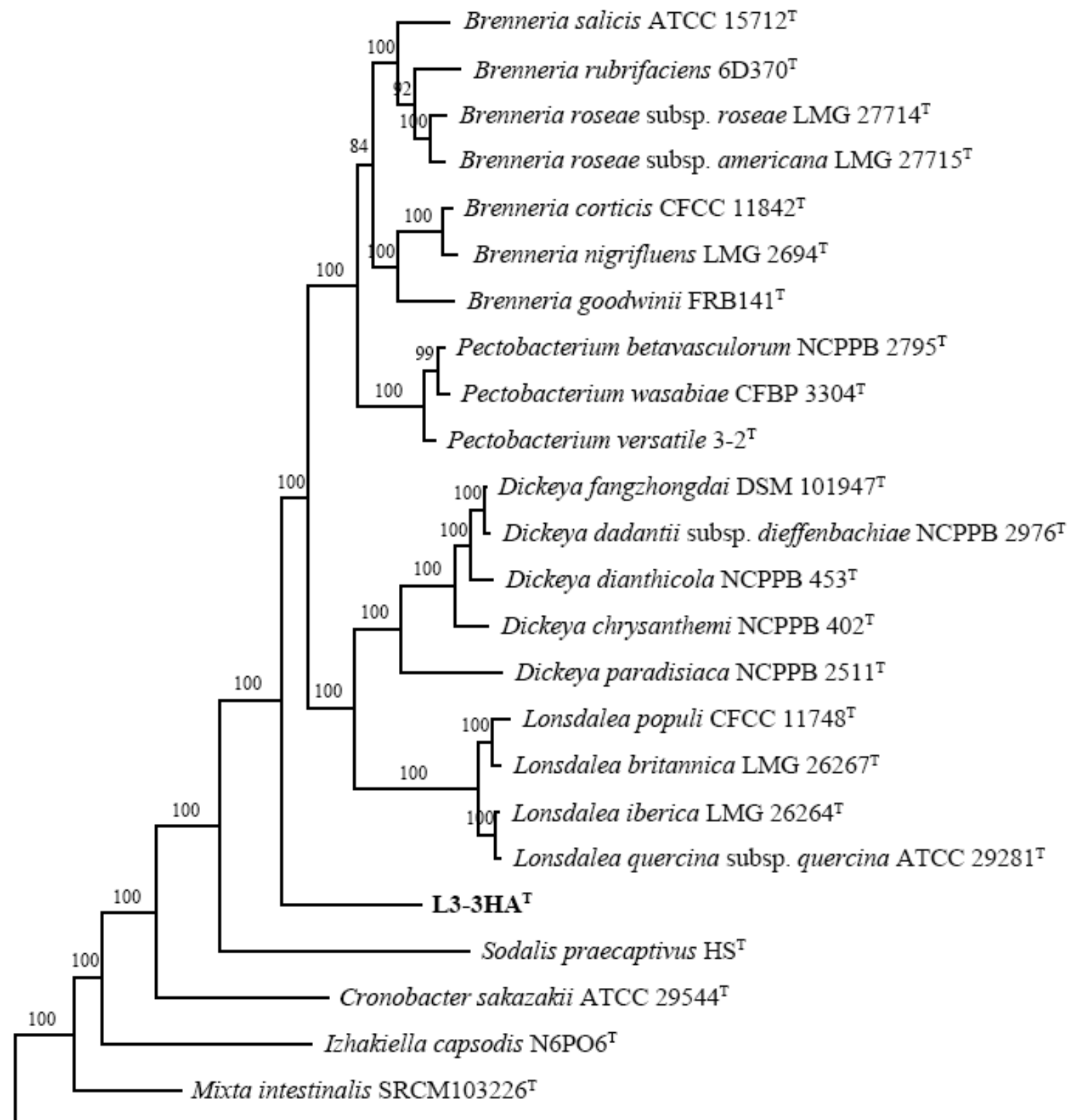

Pantoea dispersa CCUG $25232^{\mathrm{T}}$

Pantoea stewartii subsp. stewartii DC283 ${ }^{\mathrm{T}}$

Divergence, substitutions/site

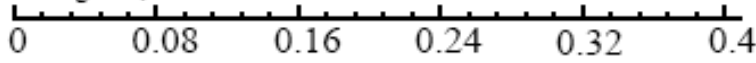

\section{Figure 3}

The phylogenetic ML tree was constructed based on the resulting multiple alignments using PhyML V3.3. The genomic coding sequences were clustered using CD-HIT v4.6.1. Four hundred sixteen single-copy genes were selected using Perl scripts and aligned using MUSCLE 3.8.31. The level of support for internal branches was assessed using the Bayesian test in PhyML.

\section{Supplementary Files}


This is a list of supplementary files associated with this preprint. Click to download.

- Supplefile20201216.docx 